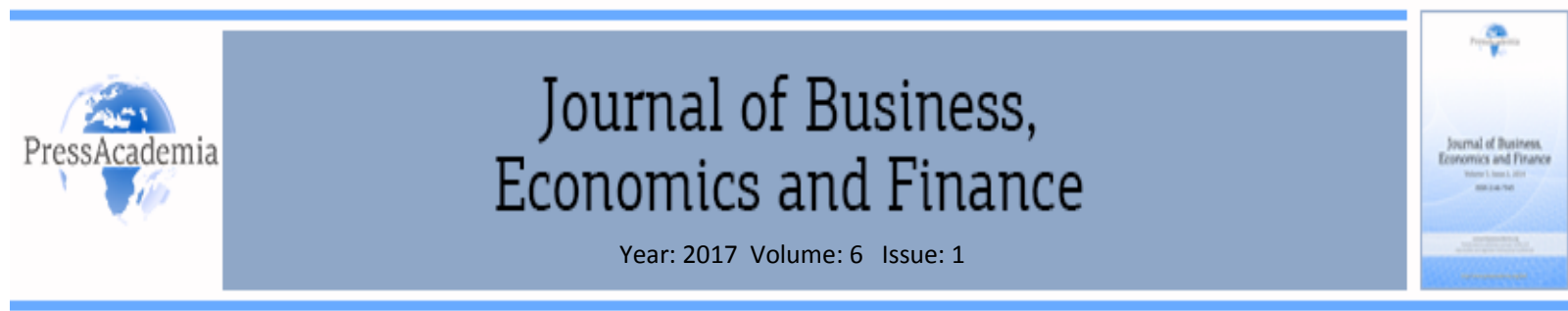

\title{
PROBLEMS FACED BY INTERNATIONAL FIRMS IN DEVELOPING COUNTRIES DUE TO EXCHANGE RATE FLUCTUATIONS: A CRITICAL STUDY OF INTERNATIONAL FIRMS IN TURKEY
}

\author{
DOI: 10.17261/Pressacademia.2017.381 \\ JBEF-V.6-ISS.1-2017(2)-p.8-16 \\ Yaw Frimpong Ofori Atta \\ Anadolu University, Department of Finance, Yunus Emre Campus, Eskisehir, Turkey. yfoa@anadolu.edu.tr
}

To cite this document

Atta, Y.F.O., (2017). Problems faced by international firms in developing countries due to exchange rate fluctuations: a critical study of international firms in Turkey. Journal of Business, Economics and Finance (JBEF), V.6, Iss.1, p.8-16.

Permemant link to this document: http://doi.org/10.17261/Pressacademia.2017.381

Copyright: Published by PressAcademia and limited licenced re-use rights only.

\begin{abstract}
Purpose- Exchange rate fluctuations and instability have rekindled interest of researchers in the subject of relationship between international trade and exchange rate. This study focused on the impact of exchange rate on international trade churning out various problems faced by international firms in developing countries specifically in Turkey.

Methodology- A bi-variate framework was employed in the study for exchange rate and foreign trade. The study used the VAR approach and VAR granger causality in the identification of long run co-integration and causality. Data used was between 1975 and 2014.

Findings- It was found that there was no directional granger causality between exchange rate and foreign trade in Turkey. However, diverse dynamic linkages were found between exchange rate and foreign trade in Turkey using Impulse Response Functions.

Conclusion- The study concluded that, international firms in Turkey are not singularly motivated by exchange rate increase or decrease to engage in international trade.
\end{abstract}

Keywords: Exchange rate, foreign trade, international firms, VAR, impulse response function JEL Codes: F23, F31, C53

\section{INTRODUCTION}

The recent trend of exchange rate relating to its instability and fluctuations has rekindled interests in the subject of international trade and exchange rate. The influence of exchange rate fluctuations is evidenced to have negative impact on foreign trade as its growth has been impeded (Ozturk, 2006) in developed and less developed countries (Arize et al, 2000). It is not unusual if not so many people are interested in the movements in a country's currency if it has a virtually closed economy. However, market participants, investors, firms and individuals become sensitive to currency movements if their economy opens up or becomes internationalized where their major decisions are subjected to exchange rate movement which has impact on trade and finance (Freiden, 2008). The major players in foreign/international trade, in other words international firms, are the ones that bear the primary consequences, whether positive or negative, of exchange rate fluctuations.

In analysing exchange rate fluctuations and trade flows with evidence from the European Union, Dell'Ariccia, (1999) found that, there is a depressing effect of exchange rate uncertainty on international trade even though the extent to which 
exchange rate volatility negatively affected trade was very small. In 13 Less Developed Countries (LCD's) Arize et al (2000) posited that, exchange rate uncertainty resulting from volatile/fluctuating exchange rate has a substantial adverse effect on export demand in the short and long runs influencing the decision of "market participants" (in this regard international firms) to explore other markets aside international trade. The impact of exchange rate fluctuations is anticipated to be higher especially in developing countries like Turkey. Turkey is a country that has many trade partners around the globe with exports contributing significantly to GDP growth between 2002 and 2008 (Dincer and Kandil, 2008) and has undergone currency crises that have been debated on by the European Monetary Union (Freiden, 2008).

International trade refers to the exchange of goods, services, factors or production between traders across borders or markets. International firms are therefore, the various firms or organizations involved in the exchange of goods and services (imports and exports) across international markets. Exchange rate fluctuations refer to the change in value of one currency against another currency due to various economic factors. When these fluctuations or movements in the exchange rate are not ultimately expected, the probability of international traders to divert investment from import/export to indigenous markets is high. These movements lead to increase in exchange rate volatility which in turn increases risk hence the diversity of investment (Dell'Ariccia, 1999).

Knowledge of the problems faced by international firms in developing countries due to exchange rate fluctuations may aid in the decision making processes of existing and emerging international firms. Inasmuch as several studies have been conducted on the subject of international trade, problems faced by international firms engaged in international trade, especially in developing countries have not received lots of attention from researchers. Therefore, using a Variance Autoregression (VAR) system, this paper puts forward an empirical investigation into the impact of exchange rate fluctuations on international trade churning out problems faced by international firms in developing countries as a result of fluctuating exchange rates with a focus on international firms in Turkey.

\section{LITERATURE REVIEW}

There have been mixed results as to the impact of exchange rate fluctuations on foreign trade. The IMF's study of exchange rate volatility and world trade in 1984 and 2004 found evidence that the impact of exchange rate volatility on international trade was not significant even though conceding that presence of bilateral trade, exchange rate misalignments and other factors have the tendency to reduce trade levels (IMF Research Dept., 1984; Peter et al 2004)

Wang (2002) suggests two aspects of risks that are meted out by exchange rates on Multinational Companies (MNC's) namely; transaction and operations risks. These risks are encountered due to: the 'rights' and 'obligations' that emerge as a result of the operations of MNC's (transaction risk); and the impact on operating cash flow when there is an unanticipated change in the supply and demand of the market (operation risk). Nonetheless, arguments from previous studies suggest that, the issue of these and other risks associated with exchange rate volatility are not considered urgent in international trade (Frieden, 2008) since such risks are being hedged against by firms using derivative instruments such as forward, options, and swap contracts (Ethier, 1973; Wang, 2002).

In their paper, 'the relationship between exchange rates and international trade: a review of economic literature', Aubion and Ruta, (2011) observed the impact of exchange rate fluctuations from a macroeconomic perspective. They suggested that exchange rate fluctuations have significant impact on the economy stemming from their effect on investment and production, which results in "inefficient allocation of domestic absorption and external trade", the working front and prices. From this same perspective and according to Dincer and Kandil (2008), it is assumed for a period of time that, there is a component of steadiness in exchange rate fluctuations relative to the changes in macroeconomic fundamentals. They as well suggested contrasting outcomes of exchange rates fluctuations resulting from "complexity of demand and supply channels". For instance, in the goods market an unexpected appreciation of the local currency has an adverse effect on exports but increases imports and subsequently deepening competition between foreign and indigenous markets.

In the quest to understand the impact of exchange rate fluctuations on the competitiveness of business, Chawla (2011) opined that, in the face of globalization and competition, there are declines in profit levels of market participants, thus, the essence of exchange rate stability must take centre stage and given necessary attention. In this study, Chawla (2011) analysed the exports and imports relation of India and the US between 2001 and 2011 and found that there was no substantial evidence of correlation existing between real effective exchange rate and annual exports as well as imports. However, competiveness in India's exports is based on effective cost and product differentiation.

Using a "heterogeneous-firm trade model' from a disaggregated Chinese data, Li et al (2015) found in their study that, there is always the tendency for firms to import more when the local currency appreciates which increases import value of firms. This sensitive phenomenon was found to be significant in firms engaged in ordinary trade than those in processing trade. An empirical evidence by same study suggested and confirmed the model that, there was a substantial increase in the likelihood of higher imports per the appreciation of domestic currency accounting for China's increased import from 2000 
to 2006. Kandil et al (2006) also indicated that depreciation of a domestic currency has two sides to it. On one side, it brings down the prices of exports and on the other side raises the price of imports. Hence, there is a probability of a set off between imports and export price subject to a stable and unchanged balance of trade and terms of trade. Nonetheless, if there is an imbalance e.g. imports exceeding exports, the end result is a reduction in an economy's real income (Kandil et al, 2006).

Past studies (Hooper and Kohlagen, 1978; Medhora, 1990; Arize et al, 2000) have argued that: increased exchange rate fluctuation/volatility spell higher cost for risk-averse traders thus reduces foreign trade. This is due to the fact that exchange rates are normally agreed upon as a part of the trade's contract thus payment made following delivery. Subject to unpredictability of the exchange rate in this situation, it affects the profit and hence reduction of proceeds in international trade. Also, other studies posited that, Less Developed Countries (LCD's) faced problems with hedging, since not all traders or firms gain access to forward markets due to its limited presence in various countries. Costs involved and other limitations were found to hamper hedging activities even after traders gain access to forward markets.

Larger exporting firms are deemed to have fewer problems relative to exchange rate fluctuations due to their ability to hedge as compared to smaller firms. The relative large nature of contract, short maturity periods and considerable high fees limit the access of smaller firms to hedging contracts (Aubion and Ruta, 2011). Nonetheless, exporting firms that are able to hedge against exchange rate movements end up landing on higher export prices due to the hedging cost and the uncertainty of exchange rate negatively affecting international trade (Obstfeld and Rogoff, 1998).

The cost involved in setting up an export or import business, "sunk cost", substantially determines a firm's quest to enter or exit a foreign trade. Past studies by; Dixit, 1989, Krugman 1986, Franke 1991, Aubion and Ruta, 2011, suggest that, during exchange rate fluctuations, firms adapt the "wait-and-see" measure during the short term, especially considering the sunk cost. Nevertheless, the longer the fluctuation may persist, the increased urge to reconsider international trade option and stay out to reallocate same resources to the indigenous market which may be considerably profitable.

\section{DATA}

The effect of exchange rate fluctuations on international/foreign trade is deemed empirical issue since theory alone cannot ascertain the very relations between international trade and exchange rate fluctuations (Arize et al, 2000).

Various impacts have been felt in the development of the Turkish economy resulting from changes in exchange rate and its broad effect on foreign trade. Turkey is perceived as an emerging economy with highly regulated but liberal financial markets. Thus, financial variables receive variations from the market activities and are as well exposed to uncontrolled external shocks (Dincer and Kandil, 2008). This study establishes an investigation into impact of exchange rate fluctuations on international trade to churn out the various problems encountered by international firms in Turkey.

The study employed yearly foreign trade volume and exchange rate data for Turkey in the analysis. The secondary data for this study was obtained from the databases of Turkish Statistical Institute (TURKSTAT) and the World Bank.

Exchange rate employed by the study is the 'Official exchange rate' which refers to the "rate determined by national authorities or to the rate determined in the legally sanctioned exchange market. It is calculated as an annual average based on monthly averages (local currency units relative to the U.S. dollar)" (World Bank) ${ }^{1}$

Foreign trade on the other hand is the "total of export and import of a country over a certain period of time (generally in a year)" (Turkish Statistical Institute) $)^{2}$. The data used was yearly in nature which spans from 1975 to 2014.)

\section{METHODOLOGY}

In order to ascertain causality among foreign trade and exchange rate fluctuations, procedural stages are presented in this section. The study employed the VAR system comprising three steps. The first step takes care of the time series stationary properties where Augmented Dicker Fuller is used as unit root tests. Following same order stationary by all the variables, the Johansen Cointegration test was applied in order to conclude if there existed a cointegration equation in the system. Secondly, Vector Autoregression (VAR) was used based on the absence of a long run cointegration in the system. The last step investigated the dynamic linkage between foreign trade and exchange rate using Impulse Response Function which doubles as a tool of VAR.

Results of the VAR system gave a basis for the relationship between exchange rate and foreign trade and a subsequent identification of the various problems faced by international firms involved in foreign trade as a result of exchange rate fluctuations.

\footnotetext{
${ }^{1}$ http://data.worldbank.org/indicator/PA.NUS.FCRF (Assessed on April 23, 2015)

2 http://www.turkstat.gov.tr/PreTablo.do?alt id=1054 (Assessed on April 23, 2015)
} 


\section{Vector Autoregression Analysis (VAR)}

The VAR model is an important and popular tool for cointegration in recent economic studies. It is mostly useful in both bivariate and multivariate time series analyses. This model encompasses the evolution and the interdependencies between multiple time series, generalizing the univariate autoregressive (AR) model. A significant importance of using the VAR model is that, all variables are considered endogenous and gives a description of the evolution of $K$ variable in the system over the same time $\mathrm{t}=(1, \ldots . . \mathrm{T})$ (Gujarati \& Porter, 2009).

A reduced $p$ th order VAR can be written as;

$Y_{t}=c+\rho_{1} Y_{t-1}+\ldots \ldots . .+\rho_{p} Y_{t-p}+\varepsilon_{t}$.

Expressing the above in the bivariate vector form,

$\left(\begin{array}{l}X R \\ F T\end{array}\right)=\left(\begin{array}{l}C 1 \\ C 2\end{array}\right)+\left(\begin{array}{ll}A 1,1 & A 1,2 \\ A 2,1 & A 2,2\end{array}\right)+\left(\begin{array}{l}X R t-1 \\ F T t-1\end{array}\right)+\cdots+\left(\begin{array}{ll}A 1,1(p) & A 1,2(p) \\ A 2,1(p) & A 2,2(p)\end{array}\right)+\left(\begin{array}{l}X R t-p \\ F T t-p\end{array}\right)\left(\begin{array}{c}\varepsilon t \\ \varepsilon t\end{array}\right)$

Where $\mathrm{XR}=$ Exchange Rate, $\mathrm{FT}=$ Foreign Trade, $\mathrm{A}=$ individual coefficients of the lagged variables and $\varepsilon$ are the error terms.

\section{EMPIRICAL RESULTS}

The empirical results of the study are presented in this section bringing forth the causal relationship between exchange rate and foreign trade.

\section{The empirical results on the causal relations between exchange rate and foreign trade}

Within the time series analysis, stationarity test commences the process. This test is conducted to ascertain the presence of unit root in the variables. Foreign trade and exchange rate were found to be stationary after first differencing using Augmented Dickey-Fuller Test. The table (1) below indicates a presentation of the stationarity test for the variables.

\section{Table 1: Unit Root Tests}

Augmented Dickey Fuller (ADF) Test for Stationarity

\begin{tabular}{|l|c|c|c|}
\hline Variable & ADF Test statistic & P value & Results \\
\hline Foreign Trade & -6.54 & $0.000^{*}$ & $\mathrm{I}(1)$ \\
\hline Exchange Rate & -3.10 & $0.03^{*}$ & $\mathrm{I}(1)$ \\
\hline
\end{tabular}

Number of observations $=38$

*significance at $5 \%, \operatorname{Lag}(0)$

The ADF test as indicated by the table above shows that Log of foreign trade and exchange rate were stationary after the first difference. To this end, the variables could be used for the Johansen test of cointegration.

As stated earlier, the study used the Johansen Cointegration test to examine the presence of cointegration equation in the VAR system. This test connotes the long run relationship or association between variables. The trace test and Maximum Eigen value test were used in ascertaining cointegrating equations that existed in the model. Table 2 below presents the results of the Johansen cointegration tests ${ }^{3}$. The trace statistic showed that, no cointegrating equations existed between foreign trade and exchange rate. Maximum Eigen value test, in the same manner indicated the nonexistence of cointegrating equations in the model.

Table 2: Cointegration Tests

Trace Test

\begin{tabular}{|l|c|c|c|}
\hline Hypothesized number of CE(s) & Trace Statistic & $\mathbf{0 . 0 5}$ critical value & Prob \\
\hline None* & 8.43 & 15.49 & 0.42 \\
\hline At most 1 & 3.24 & 3.84 & 0.07 \\
\hline
\end{tabular}

\footnotetext{
${ }^{3}$ Selection of an appropriate lag is essential aspect of the cointegration process. In order to achieve this, sequential modified LR test statistic (each test at 5\% level), Final Prediction Error (FPE), Akaike information criterion (AIC), Schwarz Information Criterion (SC), and Hannan-Quinn information criterion (HQ) were used. Lag 1 was the most appropriate lag using these criteria. A residual test was done to check for autocorrelation at lag 1 using the VAR Residual LM test and the null hypothesis of no serial correlation was not rejected.
} 
Maximum Eigen Value Test

\begin{tabular}{|l|c|c|c|}
\hline Hypothesized number of CE(s) & Eigen Value & Max-Eigen statistic & Prob \\
\hline None* & 0.13 & 5.20 & 0.72 \\
\hline At most 1 & 0.08 & 3.24 & 0.07 \\
\hline
\end{tabular}

From the table above it can be concluded that no cointegrating equations exist since the probability value of no cointegrating equation is more than 0.05 .

Subsequently, and as stated earlier, VAR model in first differences of the variables with one lag is estimated paving way for Granger causality test and to compute the Impulse Response Functions (IRF).

Since the results indicated no cointegration between variables, estimate of a VAR model in first differences of the variables with one lag was carried out, Granger causality test was done and the Impulse Response Functions were computed.

\section{VAR Granger Causality}

This test was conducted in order to enable the study ascertain the directional causality of the variables in the VAR system. Below (table 3 ) is a tabular presentation of the results indicating no directional causality between exchange rate and foreign trade.

Table 3: VAR Granger Causality

\begin{tabular}{|c|c|c|c|c|}
\hline Dependent Variable & Foreign Trade & & & \\
\hline Excluded & Chi-sq & df & Prob & Direction \\
\hline Exchange Rate & 3.60 & 1 & 0.0576 & Foreign Trade------ Exchange Rate \\
\hline Dependent Variable & Exchange Rate & & & \\
\hline Excluded & Chi-sq & $\mathrm{df}$ & Prob & Direction \\
\hline Foreign Trade & 2.78 & 1 & 0.096 & Exchange Rate ----Foreign Trade \\
\hline
\end{tabular}

*----- means no directional causality

Granger causality test normally indicates direction of causality, therefore to indicate the sign of the causality, IRFs between the two variables were used. 


\section{Impulse Response Functions}

Response to Cholesky One S.D. Innovations \pm 2 S.E.

Response of LFT to LFT

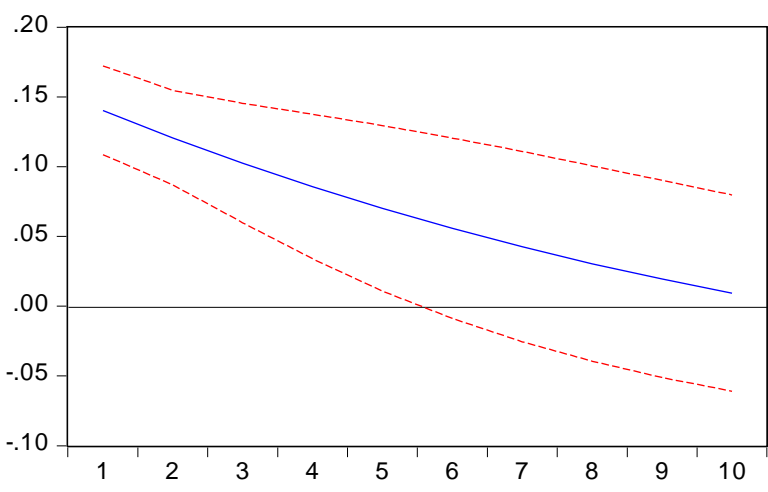

Response of LXR to LFT

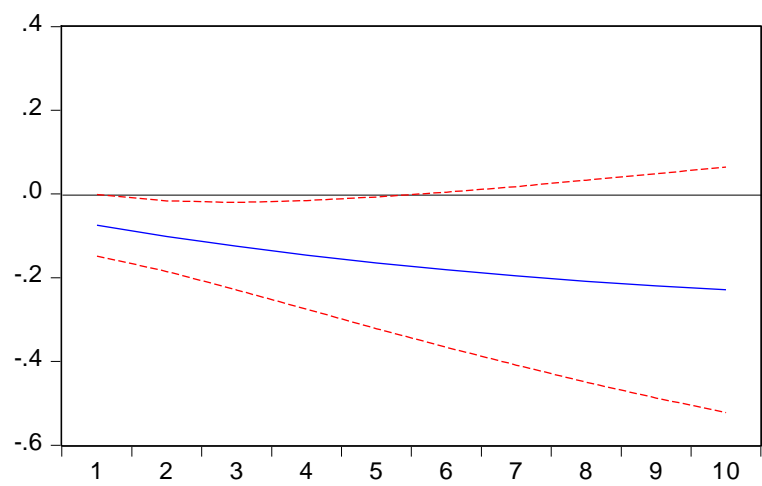

Response of LFT to LXR

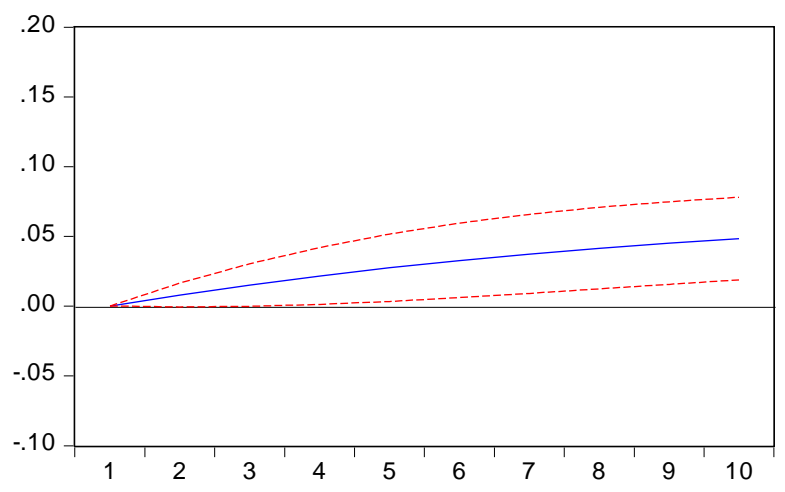

Response of LXR to LXR

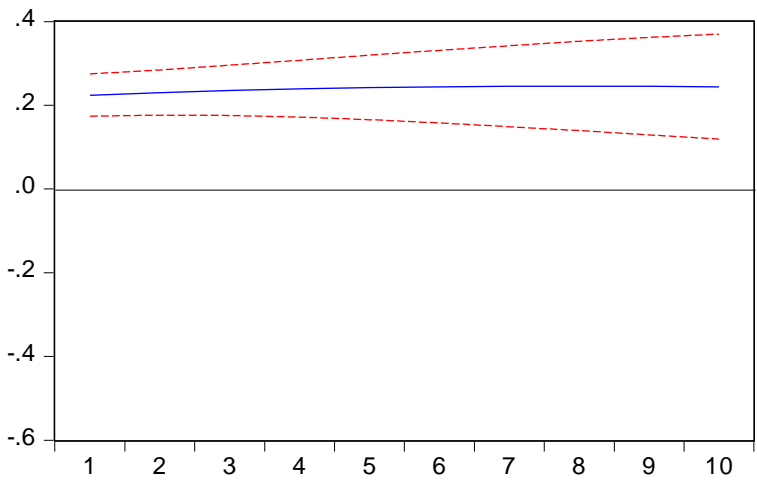

Taking a closer look at the graph above, there seems to exist dynamic linkages between exchange rate and foreign trade. A shock to foreign trade has a positive downward response to itself and in the same manner innovation applied to exchange rate gives a positive dynamic linkage to foreign trade, however this response rises slowly. Conversely, a standard deviation shock applied to foreign trade shows a negative dynamic linkage with exchange rate. Shock applied to exchange rate shows a straight line trend to itself. The dynamic linkage is however positive.

\section{Problems faced by international firms as a result of exchange rate fluctuations}

The above analysis using the VAR system has paved way for the identification of the various problems possibly encountered by international firms. The analysis (VAR Granger Causality) indicated that, there is no directional causality between exchange rate fluctuations and foreign trade. This notwithstanding the Impulse Response Functions (IRF) test indicated dynamic linkages between exchange rate and foreign trade.

\section{Operating exposure}

It is argued that exchange rates have the probability of having a serious impact on operating profit (termed operating exposure $)^{4}$ on businesses especially companies with assets and liabilities stated in currencies aside domestic currency (Lessard and Lightstone, 1986). Having determined non-directional causality between foreign trade and exchange rates, the

\footnotetext{
${ }^{4}$ See Lessard and Lightstone, 1986
} 
subject of operating profit exposure can be termed a problem encountered by firms engaged in international trade. These companies, even when not engaged in foreign operations, face stiffer competition in the domestic market as a result of the positive dynamic linkage of exchange rate to foreign trade.

The operating exposure can be controlled when companies enter into forward contracts to hedge against it. Again, operating exposure can be managed if companies are able to build factories or plants in trading partners' countries. By so doing, even though they forgo economies of scale, they stand a better chance to reduce negative impact associated with exchange rate fluctuations (Lessard and Lightstone, 1986).

\section{Indecision in contracts}

Exchange rate fluctuations plunge international firms into indecision during contractual agreements relating to foreign trade or business. There is a probability of a firm in Turkey that has made a $\$ 10 \mathrm{~m}$ deal, to end up having an amount far lesser/higher than the original amount as a result of exchange rate fluctuation. The strength and performance of businesses are partly contingent on the decisions taken. Indecision on contracts would negatively impact on the operations of firms.

Firms can therefore strengthen their finance and research and development (R\&D) departments, equip and adequately resource them to conduct requisite research to give proper predictions relative to the behaviour of their major trading currencies and to advice management accordingly.

\section{High costs of hedging}

Hedging is deemed the relative best option in reducing the problem of exchange rate volatility. In the quest to hedge, firms face extra cost due to an extra compensation demanded by the risk-bearing party in the foreign trade contracts. The uncertainty normally associated with future spot exchange rates which calls for forward markets tend to put additional costs on the risk-bearing firms since forwards markets do not insure against nominal foreign exchange risk in entirety. The risk premium demanded are subsequently added to the prices of goods traded in order to cover the fluctuations unanticipated which cause high prices for internationally traded goods (Maskus, 1986).

Having resourced the research and development department to undertake adequate research, and applying cost effective methods, the problem of high hedging cost can be taken care of as well as a reduction in the cost of production.

\section{Reduction in volume of trade}

Firms engaged in international trade (import and export) like any other businesses have profitability objectives. International firms in Turkey resort to reduced trading volumes due to exchange rate fluctuations, which create uncertainties in international transactions. As a result of an unexpected depreciation in the Turkish Lira (TL) relative to the currency partners (especially the Euro and Dollar), the Lira value of international purchase contract entered into for an upcoming period (e.g. 2 months) rises. Firms engaged in importing raw materials may be discouraged and subsequently import less of the materials. The cotton/textile industry in Turkey which accounts for about $3.7 \%$ of world's cotton yarn and textile production ${ }^{5}$ faces the same problem and probably a reduction in volume of export due to exchange rate volatility.

\section{Flow of capital restrictions}

Many international firms expect to increase trade volume, profitability and a higher return on shareholders' equity. A highly volatile exchange rate in the country would restrict the international flow of capital, which would negatively impact on direct investment in foreign operating facilities and financial portfolio investments. Since foreign direct investment (FDI) is unattractive as a result of exchange rate fluctuations, international firms in Turkey face the problem of growth, expansion and increased production.

\section{CONCLUSION}

This article sought to ascertain the impact of exchange rate fluctuations on international trade and to identify the problems faced by international firms in Turkey. By the empirical analysis using VAR approach, it was identified that, foreign trade does not granger cause exchange rate fluctuations and vice versa. This implies that, international firms are not singularly motivated by exchange rate increase or decrease to engage in international trade. The IRFs indicated that there are various dynamic linkages between foreign trade and exchange rates. To this end, it is recommended that, other factors like an enabling environment that would attract more firms which would engage in foreign trade must be embarked upon by government. These factors may include reduction in monetary policy rate which would enable firms to access credit facilities from financial institutions to set up or expand their existing international businesses.

\footnotetext{
${ }^{5}$ http://www.yourarticlelibrary.com/industries/leading-producers-of-cotton-yarn-in-the-world/25406/Assessed on April 30, 2015.
} 
Moreover, a reduction in taxes and quick access to information concerning foreign trade must be prioritized in government policies to encourage more firms to engage in international trade.

It was identified that; operating exposure, indecision on contracts, high cost of hedging, reduction in volume of trade, and flow of capital restrictions were some of the problems encountered by international firms as a result of exchange rate fluctuations. These problems can be controlled when firms:

- $\quad$ create and/or equip their research and development departments;

- set up plants or factories in partner countries;

- engage government in dialogue in relation to speeding up processes involved in investments by foreign companies;

- create a marketing niche for their products to attract patronage from partner countries.

Creation and maintaining an economy that enjoys a liberalized capital market can be recommended. Government institutions could formulate policies in line with the above stated recommendations to help international firms operate in a more stable economic environment and control or reduce the problems associated with exchange rate fluctuations.

\section{REFERENCES}

Arize, A.C., 1997, "Conditional exchange-rate volatility and the volume of foreign trade: Evidence from seven industrialized countries", Southern Economic Journal, pp.235-254.

Arize, A.C., Osang, T. and Slottje, D.J., 2000, "Exchange-rate volatility and foreign trade: evidence from thirteen LDC's", Journal of Business \& Economic Statistics, 18(1), pp.10-17.

Auboin, M. and Ruta, M., 2011, "The relationship between exchange rates and international trade: a review of economic literature", WTO Staff Working Paper, ERSD-2011-17.

Chawla, C.P., 2011, "Understanding the impact of exchange rate fluctuation on the competitiveness of business", Journal of Opinion, 1, no. 1.

Dincer, N., \& Kandil, M. 2011, "The effects of exchange rate fluctuations on exports: A sectoral analysis for Turkey", The Journal of International Trade \& Economic Development, 20(6), pp. 809-837.

Frankel, J.A., 2003, "Experience of and lessons from exchange rate regime in emerging economies", National Bureau of Economic Research (NBER) Working Paper, No. 10032.

Frieden, J., \& Zedillo, E. 2008, “Globalization and exchange rate policy”. The Future of Globalization”, New York: Routledge, pp. $344-357$.

Dell'Arricia, G. 1999, “Exchange Rate Fluctuations and Trade Flows”, IMF Staff Papers, Vol. 46, No. 3, pp. 315-334.

Goldstein, M. 1984, "The exchange rate system: Lessons of the past and options for the future", IMF occasional Paper No. 30.

Gonenc, H., Buyukkara, G. Z., \& Koyuncu, O. 2012, "Balance Sheet Exchange Rate Exposure, Investment and Firm Value: Evidence from Turkish Firms", Central Bank Review, 3(2), pp. 1-25.

Gujarati, D.N. \& Porter, D.C., 2009, "Causality in economics: The Granger causality test. Basic Econometrics", Tata McGraw-Hill Education, pp.652-658.

Hooper, P., \& Kohlhagen, S. W. 1978, "The effect of exchange rate uncertainty on the prices and volume of international trade", Journal of International Economics, 8(4), pp. 483-511.

International Monetary Fund. Research Dept. 1984, "Exchange rate volatility and world trade”, IMF occasional Paper No. 28.

Kamil, H. 2012, "How Do Exchange Rate Regimes Affect Firms' Incentives to Hedge Currency Risk? Micro Evidence for Latin America", IMF Working Paper No. 12/69.

Kandil, M., Berument, H., \& Dincer, N. N. 2007, "The effects of exchange rate fluctuations on economic activity in Turkey", Journal of Asian Economics, 18(3), pp. 466-489.

Kandil, M., \& Mirzaie, A. 2002, "Exchange rate fluctuations and disaggregated economic activity in the US: theory and evidence", Journal of International Money and Finance, 21(1), pp. 1-31.

Kapila, P., \& Hendrickson, C. 2001, “Exchange rate risk management in international construction ventures", Journal of Management in Engineering,17(4), pp. 186-191.

Kollmann, R. 2001, "The exchange rate in a dynamic-optimizing business cycle model with nominal rigidities: a quantitative investigation", Journal of International Economics, 55(2), pp. 243-262. 
Lessard, D. R., \& Lightstone, J. B. 1986, “Volatile Exchange-Rates Can Put Operations At Risk”, Harvard Business Review, 64(4), pp. 107-114.

Li, Y. A., Xu, J., \& Zhao, C. C. 2015, “Import response to exchange rate fluctuations: A micro-level investigation”, HKUST IEMS Working Paper No. 2015-27.

Maskus, K. E. 1986, “Exchange rate risk and US trade: a sectoral analysis”, Economic Review, 71(3), pp. 16-28.

Medhora, R. 1990, "The effect of exchange rate variability on trade: The case of the West African Monetary Union's imports", World Development, 18(2), pp. 313-324.

Nicita, A., 2013, “Exchange rates, international trade and trade policies”, International Economics, 135, pp.47-61.

Obstfeld, M., Cooper, R. N., \& Krugman, P. R. 1985, "Floating exchange rates: experience and prospects", Brookings Papers on Economic Activity, pp. 369-464.

Ozturk, I. 2006, "Exchange rate volatility and trade: A literature survey", International Journal of Applied Econometrics and Quantitative Studies, 3(1).

Özkanlı, Ö., Benek, S., \& Akdeve, E. 2006, "Export barriers of small firms in Turkey: A study of Ankara-Ivedik Industrial District", Problems and Perspectives in Management, 4(3), pp. 78-90.

Clark, P., Tamirisa, N., Wei, S.J., Sadikov, A. and Zeng, L., 2004, “Exchange rate volatility and trade flows-some new evidence”, IMF Occasional Paper, 235.

Solakoglu, M. N., \& Demir, N. 2009, "Exchange-Rate Exposure and the Financial Sector", Journal of Economic and Social Research, 11(2), pp. 29-42.

Teoh, H. Y., \& Er, M. 1988, "Impact of floating exchange rates on company risk management practices: The Australian experience", School of Accounting \& Finance, University of Wollongong, Working Paper 1 .

Wang, Y. Y. 2002, "Fluctuations of Exchange Rate on the Valuation of Multinational Corporations as Taiwan's Samples", Journal of Global Business Management. 